\title{
The aerodynamic behaviour of respiratory aerosols
}

\author{
K Grosskopf \\ From International Conference on Prevention \& Infection Control (ICPIC 2011) \\ Geneva, Switzerland. 29 June - 2 July 2011
}

\section{Introduction / objectives}

Hospital acquired infections (HAIs) claim on average 90,000 lives each year in the U.S., nearly three times the number of annual highway deaths. Although fewer than $15 \%$ of HAIs are directly attributable to airborne transmission, more than a third may be caused by surface microbes aerosolized by the movement of air from building systems, people and equipment. As a result, a study was devised to use a synthetic respiratory aerosol to track the movement airborne contagion with respect to various environmental conditions in a healthcare environment.

\section{Methods}

An actual hospital was used to map the spatial dispersion of synthetic respiratory aerosols with respect to particle size, airflow, door position and healthcare worker movement between a general patient room and corridor.

\section{Results}

Respirable aerosols $0.5 \mu \mathrm{m}$ to $<1.0 \mu \mathrm{m}$ were found to exhibit distinctly different aerodynamic behaviours when compared to aerosols $1.0 \mu \mathrm{m}-10.0 \mu \mathrm{m}$. Specifically, aerosols $<1.0 \mu \mathrm{m}$ appeared to disperse randomly and uniformly throughout the test space with significantly less regard to mechanical airflow, pressure relationships, door position, and personnel movement when compared to aerosols $1.0 \mu \mathrm{m}-10.0 \mu \mathrm{m}$.

\section{Conclusion}

Since expiratory droplets $<1.0 \mu \mathrm{m}$ are believed to be both capable of carrying virus and penetrating into the alveolar region of the lung, these particles may present unique challenges for ventilation systems designed to

College of Engineering, University of Nebraska, Lincoln, USA protect the healthcare population from airborne viral transmission.

\section{Disclosure of interest}

None declared.

Published: 29 June 2011

doi:10.1186/1753-6561-5-S6-P90

Cite this article as: Grosskopf: The aerodynamic behaviour of respiratory aerosols. BMC Proceedings 2011 5(Suppl 6):P90.

\author{
Submit your next manuscript to BioMed Central \\ and take full advantage of: \\ - Convenient online submission \\ - Thorough peer review \\ - No space constraints or color figure charges \\ - Immediate publication on acceptance \\ - Inclusion in PubMed, CAS, Scopus and Google Scholar \\ - Research which is freely available for redistribution \\ Submit your manuscript at \\ www.biomedcentral.com/submit
}

